\title{
DIE EVALUERING VAN 'N ONTWIKKELINGSPROGRAM GERIG OP WERKNEMERS SE LOKUS VAN BEHEER
}

\author{
DA ELS \\ LH LINDE \\ Vakgroep: Bedryf-en Personeelsielkunde, PU vir CHO, Vanderbijlpark \\ S ROTHMANN \\ Program in Bedryf-en Personeelsielkunde, PU vir CHO, Potchefstroom
}

\begin{abstract}
Human resource development should provide for the development of an internal locus of control and autonomous behaviour, as well as for the overcoming of external control. The aim of this research was to determine the effect of a development programme aimed at the locus of control of employees in a financial institution. A two-group design with a pre-, post- and post-post-measurement was used to evaluate the programme. Twenty-eight employees were allocated randomly to either an experimental or a control group. The development programme contributed to a significant increase in the internal locus of control and autonomous behaviour of the experimental group (compared with the control group) immediately following the development programme and three months after the completion thereof.
\end{abstract}

\section{OPSOMMING}

Menslikehulpbron-ontwikkeling behoort voorsiening te maak vir die aanleer van 'n interne lokus van beheer en outonome optrede asook die afleer van eksterne beheer. Die doelstelling van hierdie navorsing was om die uitwerking te bepaal van 'n ontwikkelingsprogram wat op werknemers in 'n finansiële instelling se lokus van beheer gerig was.'n Tweegroepntwerp met' $n$ voor-, na- en na-nameting is gebruik om die effek van dié program te evalueer. Agt en twintig werknemers is ewekansig aan 'n eksperimentele en kontrolegroep toegewys. Die ontwikkelingsprogram het daartoe bygedra dat die eksperimentele groep (vergeleke met die kontrolegroep) se interne lokus van beheer en outonome optrede direk na afloop van die ontwikkelingsprogram en drie maande na die voltooiing daarvan beduidend toegeneem het.

\section{SYNOPSIS}

The dynamic environment in which organisations find themselves requires that employees should have an internal locus of control and autonomy in order to maintain realistic expectations from the work environment, cope with stress, experience job satisfaction and perform in their jobs. The construct of locus of control was developed by Rotter (1966) and is described as the extent to which individuals feel that they play a causative role in events in their lives. Individuals with an internal locus of control attribute positive and/or negative events to their own actions. An external locus of control means that positive and/or negative events are regarded as unrelated to own behaviour and therefore beyond personal control.

Previous research (e.g. Day \& Matthes, 1992; Shechtman, Gilat, Fos \& Flasher, 1996) showed that training could influence an individual's locus of control. The objective of this research was to determine the impact of a development programme on the locus of control of employees within a financial institution.

The literature (e.g. Cilliers \& Wissing, 1993; Rothmann E Sieberhagen, 1997) indicated that methods directed at facilitating self-actualisation are instrumental in stimulating an internal locus of control and autonomy. The development of self-insight (through individual counselling or a growth group) often leads to the identification of a gap in skills. Various forms of skills training are related to the stimulation of an internal locus of control (James, Charlton, Leo \& Indoe, 1991). If skills in problem solving, conflict management, communication and assertive behaviour are learned, the individual experiences more autonomy and internal control in situations.

A two-group design (the pre- and post-test control group design) was used to evaluate the development programme (Huysamen, 1993). A post-post-test was used to assess the lasting effect of the programme. The development programme was compiled based on techniques, methods and personality theories from the behaviouristic, humanistic and psycho-analytical paradigms. The training programme comprised the following components:

- Individual counselling sessions. The purpose of the individual counselling sessions was to create a climate of trust and openness

Requests for copies should be addressed to: T Groenewald, Technikon SA, Private Bag X6, Florida, 1710 and to offer participants the opportunity to think about their self-development.

- Growth group. Two days of the development programme were presented in the form of a growth group experience, and more specifically an encounter group (Rogers, 1974).

- Skills development. The skills development component of the programme was presented over two days and focused on assertiveness, interpersonal skills, conflict management and problem solving.

The sample was drawn randomly from a financial institution and included 28 individuals. These individuals were randomly assigned to the experimental group $(n=14)$ and the control group $(n=14)$. The Locus of Control Inventory (Schepers, 1995) and an interview were used to determine the effect of the development programme.

With regard to the comparison of the pre- and post-tests, the results showed that the development programme contributed to a significant increase in the internal locus of control and autonomy of the experimental group (compared with the control group). At the post-post-test (compared with the pre-test) the experimental group (compared with the control group) still showed a significant increase in an internal locus of control and autonomy. The development programme had no statistical significant impact on the external locus of control of the experimental group (compared with the control group). This could be attributed to the effect of the work environment on participants.

Die dinamiese omgewing waarbinne organisasies in Suid-Afri$\mathrm{ka}$ funksioneer, vereis dat werknemers ' $\mathrm{n}$ interne lokus van beheer en outonomie sal openbaar ten einde realistiese verwagtinge van die werksomgewing te koester (Moerdyk, 1986), stres te hanteer (Edwards, 1992), werkstevredenheid te ervaar (Rothmann \& Agathagelou, 2000; Spector, 1986) en te presteer (Adams, Adams, Rice \& Insterve, 1985). Lokus van beheer verwys na die mate waarin individue glo dat hulle gebeure in hul lewens kan beheer (interne lokus van beheer) of glo dat ander invloedryke persone in die omgewing en die noodlot gebeure beheer (eksterne lokus van beheer) (Rotter, 1966).

Daar is al aangetoon dat persone met 'n interne lokus van beheer meer suksesvol is in persoonlike verhoudinge as diegene met 'n eksterne lokus (Mayer \& Sutton, 1996). Volgens Spector (1982) is persone met ' $n$ interne lokus van beheer op hulself aangewys vir beheer, terwyl persone met 'n eksterne 
lokus van beheer afhanklik is van faktore buite hulself soos toesighouers of organisasiebeleid en -reëls vir beheer. Moerdyk (1986) wys daarop dat daar'n duidelike korrelasie bestaan tussen'n eksterne lokus van beheer aan die een kant, en passiwiteit, stadige besluitneming en onrealistiese verwagtinge van die werksomgewing aan die ander kant.

Volgens De Brabander en Hellemans (1996) ervaar individue met'n eksterne lokus van beheer gevoelens van magteloosheid en vervreemding van die self en vermy hulle uitdagings. Hierdie individue ervaar meer geestes- en fisieke siektes vanweë hul relatief hoë spanningsvlakke (Edwards, 1992). Passiewe en afhanklike gedrag is ook aansienlik laer as wanneer 'n persoon se lokus van beheer intern eerder as ekstern gesetel is (Van den Berg, 1988). Werknemers wat oor 'n interne lokus van beheer beskik, behoort meer verantwoordelikheid vir hulle werksgedrag te aanvaar, wat aanleiding kan gee tot beter werksprestasie (Adams et al., 1985).

Bogenoemde bevindings beklemtoon die noodsaaklikheid van die ontwikkeling van'n interne lokus van beheer en outonomie ter bevordering van individuele motivering en organisasie-effektiwiteit. Hierdeur word die werknemers ontwikkel tot die aanvaarding van eie verantwoordelikhede en die afleer van 'n neiging om die oorsaak van probleme buite hulself te soek.

Day en Matthes (1992), Shechtman et al. (1996) en Olivier en Rothmann (1999) se navorsing bevestig dat'n individu se lokus van beheer wel deur middel van opleiding beïnvloed kan word. Die afwesigheid van'n na-nameting in Olivier en Rothmann (1999) se navorsing bring egter mee dat die permanensie van veranderinge ten opsigte van lokus van beheer in hul navorsing nie bepaal kon word nie.

Die doelstelling van hierdie navorsing was om die uitwerking van 'n ontwikkelingsprogram op die lokus van beheer van werknemers binne'n finansiële instelling te bepaal.

\section{Lokus van beheer}

Die konstruk lokus van beheer het vanuit die sosiale leerteorie (Rotter, 1966) en attribusieteorie (Heider, 1958) ontwikkel. Die sosiale leerteorie gaan van die standpunt uit dat versterking van gedrag tot ' $n$ verhoging van verwagting lei en dat bepaalde gedrag of 'n spesifieke gebeurtenis in die toekoms deur daardie versterking gevolg sal word (Rotter, Chance \& Phares, 1972). Die potensiaal vir gedrag om plaas te vind, hou verband met die verwagting dat die gedrag tot 'n besondere versterking sal lei, en dat die individu aan die besondere versterking waarde heg (Coetzer \& Schepers, 1997).

Wat die ontwikkeling van 'n interne lokus van beheer betref, het Meichenbaum en Goodman (1971) bevind dat die toevoeging van eksplisiete selfinstruksie by modelleringstegnieke 'n beduidende gedragsverandering en beter prestasie meebring omdat die individue 'n gevoel van interne beheer ontwikkel. Hazareesing en Bielawski (1991) het bevind dat daar 'n beduidende verband bestaan tussen kognitiewe selfinstruksie gekombineer met didaktiese vaardigheidspleiding en die ontwikkeling van'n interne lokus van beheer.

Volgens Heider (1958) is die attribusieteorie gemoeid met die wyse waarop die individu inligting vanuit sy/haar omgewing benut om oorsaaklike verduidelikings vir gebeurtenisse te bied. Hierdie teorie maak dit moontlik om tydens opleidingsgeleenthede op die individu se metode van inligtingverwerking te fokus ten einde sy/haar attribute en gevoel van beheer te beïnvloed. Tydens berading kan die individu bewus gemaak word van sy/haar eie attribute (bv. selfkonsep) en die uitwerking wat dit op sy/haar interne of eksterne lokus van beheer het. In hierdie opsig behoort opleiding op kognitiewe selfinsig en verbetering van die selfkonsep te fokus.

Die analitiese teorie (Jung, 1971) fokus op die opponerende subsisteme (houdings en funksies) binne die mens. 'n Balans tussen hierdie polariteite en die oorgang van uiterlik gerigte aanpassing tot innerlik gerigte aanpassing kan tot ' $\mathrm{n}$ gevoel van beheer oor die self en die eksterne omgewing lei (Meyer, Moore \& Viljoen, 1988). Die teorie van Jung (1971) bring individuasie met die ervaring van interne beheer in verband. Individuasie behels nie slegs die aanvanklike ontwikkeling van die dominante houding (ekstroversie of introversie) en funksies (gewaarwording, intuïsie, oordeel of persepsie) van'n individu nie, maar behels ook die bewuswording van die niedominante houding (ekstroversie of introversie) en funksies (gewaarwording, intuïsie, oordeel of persepsie) wat tot beter aanpassing en verhoudings lei (Day \& Matthes, 1992). Blootstelling aan 'n groeigroep vergemaklik individuasie omdat individue daardeur aangemoedig word om hulle nie-dominante houding en funksies te ervaar deur die voortdurende terugvoer van ander. Die bewuswording van blinde kolle in die psige lei tot selfbewustheid en 'n gevoel van interne beheer (Day \& Matthes, 1992; Diamond \& Shapiro, 1973).

Die persoongesentreerde teorie van Rogers (1980) bied 'n struktuur vir individuele en groepsberading gerig op die stimulering van'n interne lokus van beheer. Hiervolgens beweeg die individu weg van die idee om te leef volgens die standaarde van ander tot die siening van hom-/haarself as 'n selfgerigte persoon met standaarde en waardes wat uit eie ervaringe geformuleer is (Rogers, 1970, 1973). Rothmann, Sieberhagen en Cilliers (1998) het bevind dat individue as gevolg van die toepassing van die metodiek van dié teorie in 'n opleidingsprogram meer selfverantwoordelikheid aanvaar het. Aansluitend hierby het Cilliers en Wissing (1993) bevind dat 'n ontwikkelingsrogram in sensitiewe relasievorming bygedra het tot die ontwikkeling van'n interne lokus van beheer.

Verskeie vorme van vaardigheidspleiding word met die stimulering van 'n interne lokus van beheer in verband gebring. Nurco et al. (1995) het bevind dat opleiding in effektiewe probleemoplossing, kommunikasie, selfhandhawing en streshantering daartoe bygedra het dat respondente groter interne beheer ontwikkel het. Volgens Johnson en Johnson (1991) het blootstelling aan 'n program wat gefokus het op selfpersepsie (in ontmoetingsgroepe), die aanleer van selfhandhawing, beroepsaardighede en onafhanklikheid en die bou van gesinsverhoudinge ' $n$ beduidende verbetering in die rigting van 'n interne lokus van beheer teweeggebring. Shechtman et al. (1996) het bevind dat 'n opleidingsprogram wat op probleemoplossings- en konflikanteringsvaardighede asook groepsberading gefokus het, bygedra tot die ontwikkeling van 'n interne lokus van beheer. Die aanleer van effektiewe konflikanteringsvaardighede in samehang met sosiale ondersteuning is deur Zhang (1994) met 'n interne lokus van beheer en 'n beter selfkonsep in verband gebring.

Stirling en Reid (1992) het 'n opleidingsprogram ontwikkel wat op deelnemende beheer gefokus het ten einde' $n$ groter interne beheer by die deelnemers te stimuleer. Die inhoud van hierdie opleidingsprogram was op die aanleer van vaardighede soos sensitiwiteit, doelwitstelling, kommunikasie, probleemoplossing, die insameling van inligting en die interpretasie van gedrag gerig. Die resultate het getoon dat opleiding in hierdie genoemde vaardighede tot interne beheer gelei het.

Die ontwikkeling van selfinsig lei dikwels tot die identifisering van gebrekkige eie vaardighede. Indien vaardighede ten opsigte van probleemoplossing, konflikhantering, kommunikasie en selfhandhawing aangeleer word, ervaar die individu outonomie en interne beheer in situasies. Dit is dus sinvol om vaardigheidsopleiding met individuele en/of groepsberading te integreer. Individuele berading, gevolg deur intensiewe groeigroepervaring met gepaardgaande vaardigheidsopleiding en aktiewe deelname van die deelnemers, sal waarskynlik tot interne beheer lei (Jorgensen \& Rothmann, 1998). Laasgenoemde bevinding word bevestig deur Olivier en Rothmann (1999) se bevinding dat 'n selfontwikkelingsrogram daartoe bygedra het dat deelnemers meer selfvertroue en groter selfaanvaarding, outonomie en 'n interne lokus van beheer ontwikkel het. 


\section{METODE}

\section{Navorsingsontwerp}

'n Tweegroepontwerp met 'n voor-, na- en na-nameting is gebruik. Dit is die voormeting-nameting-kontrolegroepontwerp (Huysamen, 1993). Die doel met hierdie ontwerp was om te bepaal wat die effek van die onafhanklike veranderlike (die ontwikkelingsprogram) op die afhanklike veranderlike (lokus van beheer van die groep) is. Alhoewel 'n Solomonviergroepontwerp meer gepas sou gewees het (omdat 'n tweegroepontwerp nie die effek van die toets-hertoets skei van die effek van die ingreep nie) (Spector, 1981), was dit prakties onmoontlik om eersgenoemde in hierdie ondersoek te gebruik.

\section{Ondersoekgroep}

Die ondersoekgroep $(\mathrm{n}=28)$ is ewekansig uit boedelberedderaars en trustbeamptes van 'n finansiële instelling getrek. Twee takke $(\mathrm{N}=128)$ van die finansiële instelling is betrek om aan die ontwikkelingsprogram deel te neem. Al die lede in die ondersoekgroep is op dieselfde posvlak en doen gelykwaardige werk. Die eksperimentele groep het drie swart en 11 wit mense (sewe vroue en sewe mans) ingesluit, terwyl die kontrolegroep uit vier swart mense en 10 wit mense (ses vroue en agt mans) bestaan het.

\section{Ontwikkelingsprogram}

Die program is aan deelnemers voorgehou as 'n selfontwikkelingsprogram. In geen stadium is geïmpliseer dat die ontwikkelingsprogram op hul lokus van beheer gerig was nie. Die ontwikkelingsprogram het uit die volgende komponente bestaan:

- Individuele gesprekke. Die doel van die individuele gesprekke (wat ongeveer 30 minute elk geduur het) was om'n klimaat van vertroue en openheid te skep. Altesaam sewe uur is an hierdie gesprekke bestee.

- Groeigroep. Die eerste twee dae van die ontwikkelingsprogram is in die vorm van 'n groeigroep aangebied. Die doel hiervan was om aan deelnemers se intra- en interpersoonlike bewustheid deur middel van ervaringsleer in die hier-en-nou aan te wakker. In hierdie navorsing is 'n ontmoetingsgroep (Rogers, 1970) gebruik. Die groeigroepervaring het 16 uur geduur, waarvan een uur aan aanvangsessies, 12 uur aan groepsessies en drie uur aan teeen etenstye bestee is. Laasgenoemde word gemeld omdat betekenisolle interaksie tussen deelnemers tydens tee- en etenstye voorgekom het.

- Terugvoer en vaardigheidsopleiding. Met die aanvang van die derde dag is die verloop van die groeigroep met deelnemers bespreek. Hierna is die konstruk lokus van beheer en persoonlikheidstipes aan deelnemers voorgehou (kyk Tabel 1). Die konstruk lokus van beheer, die faktore wat 'n eksterne of interne lokus van beheer kan aanhelp en die deelnemers se rol hierin is bespreek. Deelnemers het terugvoer gekry oor hul individuele persoonlikheidstipe volgens die Myers Briggs Type Indicator (MBTI) (Myers, McCaully, Quenck \& Hammer, 1998). Vervolgens is andag geskenk aan die ontwikkeling van interpersoonlike vaardighede en konflikhanteringsaardighede. Die vaardigheidsopleiding het 15,25 uur geduur.

TABEL 1

DIE INHOUD VAN DIE ONTWIKKELINGSPROGRAM

\begin{tabular}{lcl}
\hline DAG & AANTAL URE & AKTIWITEIT \\
\hline 1 & 8 ure & Groeigroep \\
2 & 8 ure & Groeigroep \\
3 & 60 minute & Terugvoer oor die verloop van die groeigroep \\
3 & 15 minute & Groepsbespreking oor die inhoud van die handleiding \\
3 & 20 minute & Videovertoning: Eksterne lokus van beheer \\
3 & 40 minute & Groepsbespreking: Eksterne lokus van beheer \\
3 & 30 minute & Videovertoning: Interne lokus van beheer \\
3 & 40 minute & Groepsbespreking: Interne lokus van beheer \\
3 & 50 minute & Groepsbespreking: Organisasiefaktore wat lokus van \\
& & beheer beïnloed \\
3 & 120 minute & Myers Briggs Type Indicator Terugvoer \\
4 & 120 minute & Integrasie van persoonlikheidstipes en lokus van beheer \\
4 & 40 minute & Kommunikasie en rolspel \\
4 & 45 minute & Hantering van konflik en rolspel \\
4 & 60 minute & Groeigroep oordrag van leer \\
\hline
\end{tabular}

\section{Meetinstrumente}

Die Lokus van Beheer-vraelys (LVB) (Schepers, 1995) is gebruik om die uitwerking van die ontwikkelingsprogram op deelnemers se lokus van beheer te bepaal. Die drie skale se betroubaarheid is hoër as 0,80 . Betekenisvolle korrelasies met verskeie meetinstrumente bevestig die konstrukgeldigheid van die vraelys. Schepers (1995) bevind dat die LVB met'n saamgestelde kriterium van werksukses korreleer $(\mathrm{r}=0,62)($ Both-ma \& Schepers, 1997).

In die tweede fase van die empiriese ondersoek is 'n kwalitatiewe data-insamelingsetode, naamlik persoonlike onderhoude, gebaseer op die fenomenologiese metode, vir die meting van deelnemers se ervaring van die uitwerking van die ontwikkelingsprogram gebruik (Jones, Moore \& Snyders, 1988). Die onderhoude was niedirektief, en is gevoer aan die hand van die sentrale vraag: "Wat was die effek van die ontwikkelingsprogram op u?" Die vraag is telkens gevra en is kortliks aan elke deelnemer verduidelik. Die gesprek het plaasgevind in 'n goed geventileerde lokaal met voldoende beligting. Die lokaal was toegerus met gemakstoele en 'n bandopnemer wat (met die deelnemer se toestemming) aangeskakel is sodra die gesprek begin het. Bandopnames is gebruik om seker te maak dat geen inligting verlore gaan nie (Omery, 1983). Elke deelnemer is op sy/haar gemak gestel sodra hy/sy vir die onderhoud aangemeld het. Niedirektiewe gesprekvoeringstegnieke soos aandaggewende lyftaal, refleksie, opheldering, minimale aanmoediging en stiltes is gebruik om die deelnemer te help om sy/haar ervaring mee te deel (Meulenberg-Buskens, 1989).

Die betroubaarheid van die inhoudsontleding is bevorder deur die kodering wat deur die navorser en twee onafhanklike sielkundiges gedoen is. 'n Literatuurkontrole is uitgevoer deur soortgelyke navorsing te ondersoek om gemeenskaplikhede en uniekhede van die huidige navorsing uit te lig (Krefting, 1991). Psigoloë (met agtergrond ten opsigte van navorsingsetodiek) is gevra om die navorsingsplan en toepassing daarvan na te gaan. Die navorser het gepoog om geldigheid te bevorder deur voldoende tyd met elke deelnemer te bestee sodat rapport gevestig kon word en laasgenoemde aan sy teenwoordigheid gewoond kon raak. Sosiaal gewenste response is verminder deur van gesprekvoeringstegnieke gebruik te maak. Herfrasering en herhaling van vrae is gebruik om te help om geloofwaardige inligting te verkry (Krefting, 1991).

\section{Data-ontleding}

Die statistiese ontledings is met behulp van die Statistica-program (Statsoft Inc., 1995) gedoen. Die Mann-Whitney U-toets is gebruik om die beduidendheid van verskille tussen die veranderinge in die eksperimentele en kontrolegroep te bepaal. Die interpretasie van die resultate van dié van die t-toets vir onafhanklike groepe, behalwe dat die U-toets op grond van die som van rangordes eerder as rekenkundige gemiddeldes bepaal word. Die statistiese beslissingskriterium is op die vlak van $\alpha=0,05$ gestel. Indien die resultate statisties beduidend was, is die praktiese betekenisvolheid daarvan ook bereken. Vir verskille tussen gemiddeldes is praktiese betekenisvolheid op d = 0,50 (medium effek, Cohen, 1988) gestel.

Die praktiese betekenisvolheid (d) ten opsigte van die vergelyking van die eksperimentele en kontrolegroep word weergegee deur die volgende simbole (Steyn, 1999):

$\mathrm{d}=\left(\overline{\mathrm{X}}_{\mathrm{E}}-\overline{\mathrm{X}}_{\mathrm{K}}\right) / \mathrm{S}_{\mathrm{Maks}}$

waar

$\overline{\mathrm{X}}_{\mathrm{E}}=$ die rekenkundige gemiddelde van die verskil tussen die voor-, na- en na-nametings van die eksperimentele groep,

$\overline{\mathrm{X}}_{\mathrm{E}}=$ die rekenkundige gemiddelde van die verskil tussen die voor-, na- en na-nametings van die kontrolegroep, en

$\mathrm{S}_{\text {Maks }}=$ die maksimum standaardafwyking tussen die eksperimentele en kontrolegroep.

Die bandopnames van die onderhoud is woordeliks deur die 
navorser getranskribeer, sodat inligting wat ingesamel is, ontleed kon word. Inhoudsontleding (Giorgi, 1985) is gebruik om die navorsingsdata op 'n sistematiese, objektiewe en kwantitatiewe wyse te ontleed en te vertolk (Kerlinger, 1986). Eerstens is die universum van die inhoud wat ontleed moes word, gedefinieer. Tweedens is eenhede van ontleding, naamlik woorde en temas, bepaal. Derdens is oorbodige data uitgeskakel en die betekenis van die oorblywende eenhede bepaal. Vierdens is konkrete taal wat deur deelnemers gebruik is na wetenskaplike taal en konsepte oorgeskakel. Die presiese woorde van die deelnemers is ter stawing gebruik.'n Integrasie en sintese is gedoen op grond van die insigte wat verkry is.

\section{RESULTATE}

In Tabel 2 word die verskille tussen die eksperimentele en kontrolegroep met betrekking tot die LVB gerapporteer.

TABEL 2

VERSKILLE TUSSEN DIE VOOR EN NAMETINGS VAN DIE EKSPERIMENTELE (EG) EN KONTROLEGROEP (KG) TEN OPSIGTE VAN DIE LVB

\begin{tabular}{|c|c|c|c|c|c|c|}
\hline \multirow[t]{2}{*}{ Item } & \multicolumn{2}{|l|}{ EG } & \multicolumn{2}{|l|}{ KG } & \multirow[t]{2}{*}{$\mathrm{p}$} & \multirow[t]{2}{*}{$\mathrm{d}$} \\
\hline & $\begin{array}{l}\overline{\overline{\mathrm{X}}}- \\
\text { verskil }\end{array}$ & $\begin{array}{l}\text { s- } \\
\text { verskil }\end{array}$ & $\begin{array}{l}\overline{\mathrm{X}}- \\
\text { verskil }\end{array}$ & $\begin{array}{l}\text { s- } \\
\text { verskil }\end{array}$ & & \\
\hline \multicolumn{7}{|c|}{ Voor- en nameting } \\
\hline Eksterne Beheer & $-1,21$ & 2,48 & $-0,07$ & 1,94 & 0,15 & - \\
\hline Interne Beheer & 1,78 & 2,00 & $-0,71$ & 2,39 & 0,01 * & $0,89^{++}$ \\
\hline Outonomie & 1,21 & 1,47 & $-0,28$ & 1,85 & $0,03 \star$ & $0,72^{+}$ \\
\hline \multicolumn{7}{|c|}{$\mathrm{Na}$ - en na-nameting } \\
\hline Eksterne Beheer & $-0,29$ & 3,00 & $-0,21$ & 1,31 & 0,60 & - \\
\hline Interne Beheer & $-0,71$ & 1,85 & $-0,50$ & 1,87 & 0,67 & - \\
\hline Outonomie & 0,00 & 1,35 & 0,07 & 1,14 & 0,70 & - \\
\hline \multicolumn{7}{|c|}{ Voor- en na-nameting } \\
\hline Eksterne Beheer & $-0,29$ & 2,99 & $-0,35$ & 2,16 & 0,88 & - \\
\hline Interne Beheer & 1,07 & 2,78 & $-1,14$ & 3,13 & $0,04 \star$ & $0,71^{+}$ \\
\hline Outonomie & 1,21 & 1,25 & $-0,21$ & 1,62 & $0,02 \star$ & $0,87^{++}$ \\
\hline
\end{tabular}

$\star$ Verskil is statisties beduidend: $\mathrm{p}<0,05$

+ Verskil is prakties betekenisvol: $\mathrm{d} \leq 0,50$ (medium effek).

++ Verskil is prakties betekenisvol: $\mathrm{d} \leq 0,80$ (groot effek)

Dit blyk uit Tabel 2 dat daar 'n statisties beduidende verskil ten opsigte van twee van die skale van die LVB (Interne beheer en Outonomie) betreffende die voor- en na-meting en die vooren na-na-meting is. Hierdie verskille ten opsigte van Interne beheer en Outonomie van die eksperimentele groep teenoor die kontrolegroep is prakties betekenisvol. Dit blyk dus dat die eksperimentele groep (vergeleke met die kontrolegroep) na afloop van die ontwikkelingsprogram (vergeleke met die voormeting) 'n statisties beduidend hoër en prakties betekenisvolle groei in interne lokus van beheer (groot effek) en outonomie (medium effek) getoon het. Drie maande na afloop van die ontwikkelingsprogram was daar steeds statisties beduidende en prakties betekenisvolle verskille tussen verandering in die eksperimentele en kontrolegroep se tellings op hierdie skale. Hierdie verskille kan aan die ontwikkelingsprogram en moontlik aan die toetshertoetseffek toegeskryf word. Deelnemers in die eksperimentele groep (vergeleke met die kontrolegroep) het egter geen statisties beduidende verskille ten opsigte van die verandering in Eksterne beheer getoon nie.

In Tabel 3 word die kwalitatiewe effek van die ontwikkelingsprogram weergegee.

TABEL 3

DIE KWALITATIEWE RESULTATE VAN DIE ONTWIKKELINGSPROGRAM

\begin{tabular}{lcc}
\hline Dimensie & Aantal & Rangorde \\
\hline 1. Intrapersoonlike groei & & \\
" Selfhandhawing & 5 & 6 \\
". Selfbewustheid & 7 & 1,5 \\
" Insig in die self & 6 & 3,5 \\
2. Interpersoonlike effektiwiteit & 5 & 6 \\
" Bewustheid van interpersoonlike verskille & 6 & 3,5 \\
" Interpersoonlike begrip & 7 & 1,5 \\
"Interpersoonlike bewustheid & 5 & 6 \\
" Respek vir ander & & \\
\hline
\end{tabular}

Die volgende afleidings kan op grond van Tabel 3 gemaak word:

- Tema 1: Selfbewustheid (Rangorde 1,5). Hierdie tema dui daarop dat die deelnemers in die eksperimentele groep na afloop van die ontwikkelingsprogram meer bewus geword het van hul eie gedrag. Dit beteken dat dit wat eers onbewuste gedrag was, herken is en in die bewussyn opgeneem is. Hierdie tema stem ooreen met die bevindinge van Hazareesing en Bielawski (1991) en Cilliers (1995). Die volgende stellings is deur deelnemers gemaak: "Ek dink mens leer iets van jouself...", "I realised my own abilities and weaknesses instead of reaching out to others."; "I know that I also need to be aware of my own mistakes . . .”.

- Tema 2: Interpersoonlike bewustheid (Rangorde 1,5). Hierdie tema is net so belangrik as selfbewustheid en behels die feit dat deelnemers aan die program meer bewus geword het van ander individue se gedrag. Hierdie tema word bevestig deur die bevindinge van Armstrong, Cox, Short en Allmon (1991) en Nurco et al. (1995). Die volgende verwoordings bevestig hierdie tema: ". . . she filled it in and she is more of a introverted feeler."; "So she is not the expressive type..."; "Even if a person is different from you it doesn't mean that you need to change the world."

- Tema: 3: Insig in die self (Rangorde 3,5). Deelnemers meld dat hulle 'n verbetering en verdieping verkry het in die kennis wat hul aangaande hulself het. Insig in die self word beskou as die vermoë om eie gedrag en die diepere betekenis daarvan te verstaan soos dit manifesteer. Hierdie tema word ondersteun deur die bevindinge van Cilliers (1995) dat ' $n$ bewustheid van eie gedrag ook aanleiding gee tot persoonlikheidsintegrasie. Hierdie tema blyk uit die volgende woorde: "Ek hou nie daarvan om dinge so in chaos te los nie . . . Ek haat dit."; "Ek weet ek het foute en ek wil daaraan werk, soos byvoorbeeld om stil te wees."; "Soos ek wat nou 'n introvert is, sal aanvaar dat ek as 'n introvert baie stil is, maar ander wat baie praat 'n ekstrovert is." en "Mens kan ook sê dat ek verstaan hoe ek is."

- Tema 4: Interpersoonlike begrip (Rangorde 3,5). Interpersoonlike begrip dui daarop dat die individue hulle in die verwysingsraamwerk van ander kan verplaas, ten einde meer begrip vir hulle te hê. Hierdeur word die eie persoonlike verwysingsraamwerk ondergeskik gestel ten einde dié van ander te begryp. Die tema is verwant aan die gedragsdimensie wat Rogers (1975) as empatie omskryf. Ander opmerkings wat gemaak is, is soos volg: "I came here and I saw and understood some people different"; “. . . en rassediskriminasie en ek glo dat mens na albei kante moet kyk.”

- Tema 5: Selfhandhawing (Rangorde 6). Dit kom voor of die aanleer van selfhandhawende gedrag outonome optrede en interne lokus van beheer by deelnemers ontwikkel het. Dié siening word deur die navorsing van Nurco et al. (1995) en Johnson en Johnson (1991) ondersteun. Van die deelnemers het byvoorbeeld gesê dat hulle praat wanneer dit nodig is. 'n Ander het gesê dat sy die vrymoedigheid het om werksprobleme met haar meerderes te bespreek. Deelnemers het onder andere die volgende stellings gemaak: “. . . maar ek glo dat dinge en die mense wat daar was, op so'n stadium gekom het dat hulle presies vertel het dat dit is hoe hulle voel."; "Ek het die bul by die horings gepak en vir hom gaan sê"; "dit is hoekom ek so baie terug praat, om my saak ook te kan stel".

- Tema 6: Bewustheid van interpersoonlike verskille (Rangorde 6). Dié tema dui daarop dat die deelnemer bewus is daarvan dat ander van hulle verskil. 'n Bewustheid van interpersoonlike verskille sluit die verskille ten opsigte van persoonlikheid en ras in. Een deelnemer rapporteer dat sy opnuut bewus geraak het daarvan dat daar 'n verskeidenheid tipes van mense is en dat sy die "ander kant" van hulle ervaar het.' $n$ Ander sluit hierby aan deur te rapporteer dat rasseverskil en rassediskriminasie vanuit albei perspektiewe 
beskou moet word. Frases wat hierdie tema bevestig, is soos volg: "Die eerste keer wat die Swarte gepraat het oor ons wat stil is, was dit vir my erg."; “. . . van . . . se kant het dit gevoel of hy absoluut op die blankes afpen en ek het gevoel . . . gee ons net ook'n kans."; “. . . niemand is noodwendig verkeerd nie, hulle het ander opinies en dink anders."

- Tema 7: Respek vir ander (Rangorde 6). Respek vir ander verwys na die erkenning, waardering en agting vir die waarde van ander persone en hul reg as vrye individue. Hierdie tema blyk duidelik uit opmerkings soos: "Ek sal eerder iemand anders ' $n$ kans gee om te praat en luister wat hulle sê."; "Elkeen het sy eie reg. Elkeen het'n storie om te vertel; "mens moet net luister."

\section{BESPREKING}

Dit blyk uit die resultate dat die deelnemers in die eksperimentele groep wel gunstig op die ontwikkelingsprogram gereageer het. Deelnemers het direk na afloop van die program'n verhoging ten opsigte van interne lokus van beheer en outonomie getoon, terwyl sodanige veranderinge nie in die kontrolegroep gevind is nie. Die gunstige reaksie met betrekking tot interne lokus van beheer dra daartoe by dat deelnemers sukses aan hul eie gedrag en relatief permanente per-soonlikeidsienskappe toeskryf. Verder is hulle meer geneig om in hul eie vermoëns te glo en met selfvertroue te handel. Laasgenoemde bevindings stem ooreen met dié van Olivier en Rothmann (1999).

Geen verandering in interne beheer en outonomie het tussen die nameting en die na-nameting plaasgevind nie. Daar was egter in hierdie tydperk ook geen betekenisvolle toename in die eksperimentele groep (vergeleke met die kontrolegroep) se eksterne lokus van beheer nie. Hieruit blyk dit dat die ontwikkelingsprogram nie bygedra het om 'n eksterne lokus van beheer af te leer nie. As gevolg van niedeelnemende strukture en praktyke wat deelnemers in die organisasieomgewing inhibeer, kan hul waargenome onvermoë om hul omgewing te beheer, gehandhaaf word (Spector, 1986). Die belangrike invloed wat die werksomgewing op lokus van beheer uitoefen, word bevestig deur Van Staden, Schepers en Rieger (2000) se bevindings dat interne beheer sterk met transformasionele leierskap en eksterne beheer met transaksionele leierskap korreleer.

Die kwalitatiewe evaluering het deurgaans op beter intrapersoonlike groei betreffende selfewustheid, insig in eie gedrag (en die beheer van die self), selfaanvaarding en spontaneiteit gedui. Die aanleer van vaardighede het tot meer selfvertroue en selfhandhawende gedrag gelei en die ontwikkeling van die self is as 'n langtermynproses beskou. Verbetering van interpersoonlike effektiwiteit dui op beter interpersoonlike bewustheid en begrip, bewustheid van interpersoonlike verskille en die bewuswording van interpersoonlike sensitiwiteit. Met betrekking tot interpersoonlike vaardigheid is daar ' $n$ toename in luister- en konflikanteringsvaardigheid gerapporteer. Dit gee aanleiding tot effektiewe interpersoonlike verhoudings en die konstruktiewe hantering van konflik en probleemsituasies. Die kwalitatiewe ontleding toon dus aan dat die deelnemers se coping-strategieë drie maande na afloop van die program meer konstruktief was.

Daar was veral twee leemtes in hierdie navorsing. Eerstens het die aard van die ontwikkelingsprogram, wat'n groeigroep ingesluit het, beperkings op die grootte van die ondersoekgroep geplaas, wat die veralgemeenbaarheid van die resultate beperk. Tweedens is 'n tweegroepontwerp gebruik, wat meebring dat die effek van voormeting nie uitgeskakel kon word nie.

Die resultate van hierdie navorsing impliseer dat organisasies intra- en interpersoonlike ontwikkeling as 'n langtermynproses moet benader en verdere ontwikkelingsingrepe hiervoor moet implementeer. Ontwikkelingsprogramme behoort op die intrapersoonlike groei en vaardigheidsopleiding van werknemers te fokus ten einde outonomie en 'n interne lokus van beheer by hulle te bevorder. Toekomstige navorsing moet ook fokus op veranderlikes in organisasies wat fasiliterend en beperkend op werknemers se interne lokus van beheer en outonomie inwerk. In hierdie verband behoort veral die invloed van transaksionele leierskap op werknemers se lokus van beheer ondersoek te word. Ten slotte is meer navorsing ook nodig oor die uitwerking wat voortgesette ondersteuningsgroepe op werknemers se lokus van beheer uitoefen.

\section{VERWYSINGS}

Adams, J.B., Adams, J., Rice, R.W. \& Insterve, D. (1985). Effectiveness and group role on attributions of group performance. Journal of Applied Psychology, 15, 387-389.

Armstrong, H.E., Cox, G.B., Short, B.A. \& Allmon, D.J. (1991). A comparative evaluation of two day treatment programs. Psychosocial Rehabilitation Journal, 14(4), 53-67.

Bothma, A.C. \& Schepers, J.M. (1997). The role of locus of control and achievement motivation in the work performance of black managers. Journal of Industrial Psychology, 23(3), 44-52.

Cilliers, F.V.N. \& Wissing, M.P. (1993). Sensitiewe relasievorming as bestuursdimensie die evaluering van 'n ontwikkelingsprogram. Tydskrif vir Bedryfsielkunde, 19(1), 5-10.

Cilliers, F.V.N. (1995). Fasiliteerderopleiding. Tydskrif vir Bedryfsielkunde, 21(3), 7-11.

Coetzer, E.L \& Schepers, J.M. (1997). Die verband tussen lokus van beheer en die werksrestasie van swart bemarkers in die lewensversekeringsbedryf. Tydskrif vir Bedryfielkunde, 23(1), 34-41.

Cohen, J. (1988). Statistical power analysis for the behavioral sciences (Revised ed.). Orlando, CA: Academic Press.

Day, B. \& Matthes, W. (1992). A Jungian stage theory of individual development in personal growth groups. The Journal for Specialists in Group Work, 7, 168-182.

De Brabander, B. \& Hellemans, J. (1996). Locus of control sensation seeking and stress. Psychological Reports, 79, 1307-1312.

Diamand, M.J. \& Shapiro, J.L. (1973). Changes in locus of control as a function of encounter group experiences. Journal of Abnormal Psychology, 82, 514-518.

Edwards, J.R. (1992). A cybernetic theory of stress, coping and well-being in organizations. Academy of Management Review, 17, 238-274.

Giorgi, A. (1985). Sketch of a psychological phenomenological method. In A. Giorgi (Ed.), Phenomenology and psychological research. Pittsburgh, PA: Duquesne University Press.

Hazareesing, N.A. \& Bielawski, L.L. (1991). The effects of cognitive self-instruction on student teachers' perceptions of control. Teacher and Teacher Education, 7, 383-393.

Heider, F. (1958). Psychology of interpersonal relations. New York: Wiley.

Huysamen, G.K. (1993). Metodologie vir die sosiale en gedragswetenskappe. Halfweghuis: Southern Boekuitgewers.

James, J., Charlton, T., Leo, E. \& Indoe, D. (1991). Using peer counsellors to improve secondary pupils'spelling and reading performance. Maladjustment \& Therapeutic Education, 9(1), 33-40.

Johnson, C.L. \& Johnson, J.A. (1991). Using short-term group counselling with visually impaired adolescents. Journal of Visual Impairment and Blindness, 85, 166-170.

Jones, M.O., Moore, M.D. \& Snyders, P.C. (1988). Inside organisations. Newbury Park, CA: Sage.

Jorgensen, L.I. \& Rothmann, S. (1998). Die evaluering van'n opleidingsprogram t.o.v. interpersoonlike vaardighede. Tydskrif vir Ekonomiese en Bestuurswetenskappe, 1, 377-389.

Jung, C.G. (1971). Psychological types: The portable Jung. New York: Viking.

Kerlinger, F.N. (1986). Foundations of behavioral research (3rd ed). Forth Worth, TX: Harcount Brace \& Company.

Krefting, L. (1991). Rigor in qualitative research: The assessment of trustworthiness. The American Journal of Occupational Therapy, 45, 214-222.

Mayer, F.S. \& Sutton, K. (1996). Personality: An integrative approach. Upper Saddle River, NJ: Prentice-Hall. 
Meichenbaum, D.H. \& Goodman, J. (1971). Training impulsive children to talk to themselves. Journal of Abnormal Psychology, 77, 115-126.

Meulenberg-Buskens, M. (1989). Manual for the Free Attitude Interview technique. Pretoria: HSRC.

Meyer, W.F., Moore, C. \& Viljoen, H.G. (1988). Persoonlikheidsteorieë:Van Freud tot Frankl. Johannesburg: Lexicon Uitgewers.

Moerdyk, A.P. (1986). Planning and implementing a black advancement programme. In R. Smollan, (Ed.), Black adzvancement in the South African economy. (pp. 155-177). Houndmills, Basingstake: Macmillan.

Myers, I.B., McCaully, M.H., Quenck, N.L. \& Hammer, A.L. (1998). MBTI manual: A guide to the development and use of the Myers-Briggs Type Indicator (3rd ed.). Palo Alto, CA: Consulting Psychologists Press.

Nurco, D.N., Primm, B.J., Lerner, M., Stephenson, P., Brown, L.S. \& Ajuluchukwu, D.C. (1995). Changes in locus of control attitudes about drug misuse in a self-help group in a methadone maintenance clinic. The International Journal of the Addictions, 30(6), 87- 92.

Olivier, M. \& Rothmann, S. (1999). The development of an internal locus of control in employees in the manufacturing sector. South African Journal of Economic and Management Sciences, 2, 476-491.

Omery, A. (1983). Phenomenology: A method for nursing research. Advances in Nursing Science, 5(2), 49-63.

Rogers, C.R. (1970). Carl Rogers on encounter groups. New York: Haper and Row.

Rogers, C.R. (1973.) Client-centered therapy. London: Constable.

Rogers, C.R. (1980). A way of being. Boston, MA: HoughtonMifflin.

Rothmann, S. \& Agathagelou, A.M. (2000). Die verband tussen lokus van beheer en werkstevredenheid by senior polisiepersoneel. Tydskrif vir Bedryfsielkunde, 26(2).

Rothmann, S. \& Sieberhagen, G. (1997). Die samestelling en evaluering van 'n groepfasiliteringskursus. Tydskrif vir Bedryfsielkunde, 23(3), 9-14.
Rothmann, S., Sieberhagen, G. \& Cilliers, FV.N. (1998). Die kwalitatiewe effek van 'n groepfasiliteringskursus. Tydskrif vir Bedryfsielkunde, 24(3), 7-13.

Rotter, J.B. (1966). Generalized expectancies for internal versus external control of reinforcements. Psychological Monographs: General and Applied, 80,1-27.

Rotter, J.B., Chance, J.E. \& Phares, E.J. (1972). Applications of social learning theory of personality. New York: Holt, Rinehart \& Winston.

Schepers, J.M. (1995). Die lokus van beheer-vraelys: Konstruksie en evaluering van'n nuwe meetinstrument. Johannesburg: RAU.

Shechtman, Z., Gilat, E., Fos, L. \& Flasher, A. (1996). Brief group therapy with low-achieving elementary school children. Journal of Counselling Psychology, 43, 376- 382.

Spector, P.E. (1981). Research designs. London: Sage.

Spector, P.E. (1982). Behaviour in organizations as a function of employees' locus of control. Psychological Bulletin, 91, 482-497.

Spector, P.E. (1986). Perceived control by employees: A metaanalysis of studies concerning autonomy and participation at work. Human Relations, 39, 1005-1016.

StatSoft, Inc. (1995). STATISTICA for Windows [Computer program manual]. Tulsa, OK: Statsoft, Inc.

Steyn, H.S. (1999). Praktiese betekenisvolheid: Die gebruik van effekgroottes. Wetenskaplike bydraes Reeks B: Natuurwetenskappe Nr. 117. Potchefstroom: PU vir CHO.

Stirling, G. \& Reid, W. (1992). The application of participatory control to facilitate patient well-being: An experimental study of nursing impact on geriatric patients. Canadian Journal of Behavioural Science, 24, 204-219.

Van den Berg, G.C. (1988). Perseptuele verskille tussen werknemers en bestuur ten opsigte van swart vooruitgang in die werksituasie. South African Journal of Labour Relations, 12(3), 24-44.

Van Staden, J.F., Schepers, J.M. \& Rieger, H.S. (2000). Lokus van beheer en transformasionele leierskap. Tydskrif vir Bedryfsielkunde, 26(3), 8-14.

Zhang, Q. (1994). An intervention model of constructive conflict resolution and cooperative learning. Journal of Social Issues, 50, 99-116. 